\title{
IDENTIFIKASI POLIMORFIS MARKA-MARKA MOLEKULER YANG DIDUGA BERKAITAN DENGAN KARAKTER DAYA HASIL TINGGI PADA 30 GENOTIP PADI
}

\author{
Nono Carsono ${ }^{1 *}$, Pradita N Lukman ${ }^{2}$, Farida Damayanti ${ }^{1}$, Untung Susanto ${ }^{4}$, Santika Sari ${ }^{3}$ \\ ${ }^{1}$ Laboratorium Pemuliaan dan Bioteknologi Tanaman, Fakultas Pertanian, Universitas Padjadjaran, \\ ${ }^{2}$ Program Studi Agroteknologi, Fakultas Pertanian, Universitas Padjadjaran, \\ ${ }^{3}$ Program Magister Pemuliaan Tanaman, Fakultas Pertanian, Universitas Padjadjaran, \\ Jl. Raya Bandung-Sumedang km. 21 Jatinangor, Sumedang, Jawa Barat 45363 \\ ${ }^{4}$ Staf Peneliti pada Balai Besar Penelitian Tanaman Padi (BB Padi), \\ Jl. Raya Sukamandi, Subang, Jawa Barat. \\ *Alamat korespondensi: ncarsono@mail.unpad.ac.id
}

\begin{abstract}
Abstrak: Identifikasi marka polimorfis yang diduga berasosiasi dengan karakter daya hasil tinggi sangat penting dilakukan guna aplikasi seleksi berbasis marka dalam rangka perakitan padi berdaya hasil tinggi. Penelitian ini dilakukan untuk mengidentifikasi 30 genotip padi yang diduga berdaya hasil tinggi dengan menggunakan marka SSR. Amplifikasi produk PCR dipisahkan dengan menggunakan gel agarose 3\% atau polyacrylamide gel electrophoresis (PAGE) 8\%. Tingkat keinformatifan marka dapat ditentukan dengan cara penghitungan Polymorphic Information Content (PIC). Hasil analisis menunjukan bahwa marka OSBLE3, RM 282, dan RM 259 memiliki nilai PIC $\geq 0,5$. Marka SSR dan marka gen spesifik yang digunakan untuk mengidentifikasi padi berdaya hasil tinggi menunjukkan bahwa tiga genotip padi terseleksi dapat direkomendasikan sebagai tetua donor dalam persilangan diantaranya yaitu genotip \#1 (Fatmawati), \#3 (Inpari13), dan \#30 (IPB 160-F-3-3-1). Marka molekuler yang digunakan dapat memperkirakan tingkat polimorfisme dan juga berguna untuk mengkonfirmasi genotip padi yang berpotensi daya hasil tinggi.
\end{abstract}

Kata kunci: hasil tinggi, marka polimorfis, padi, dan PIC.

\begin{abstract}
Identification of polymorphic markers that are associated with high yielding character is highly important for the application of marker assisted selection in developing such trait in rice. This study was aimed to identify SSR markers which were reported by some researchers to be associated with high yielding trait in 30 rice genotypes. PCR amplifications were separated on a $3 \%$ agarose or a $8 \%$ polyacrylamide gel electrophoresis (PAGE). The informative markers were determined by calculating the Polymorphic Information Content (PIC). The results of the analysis revealed that OSBLE3, RM 282, and RM 259 had PIC values $\geq 0.5$ which were classified as informative markers. Based on SSR and the gene specific markers applied, genotype \#1 (Fatmawati), \#3 (Inpari13), and \#30 (IPB 160-F-3-3-1) are recommended as donor parents for developing high yielding rice lines. The molecular markers applied are able to estimate the level polymorphism and useful for confirming potential high yielding genotypes.
\end{abstract}

Keywords: high yielding, polymorphic marker, rice and PIC.

\section{PENDAHULUAN}

Beras merupakan makanan pokok bagi sebagian penduduk di dunia dan terutama di Indonesia. Peningkatan produktivitas tanaman padi merupakan bagian dari upaya untuk peningkatan produksi pertanian khususnya tanaman pangan. Ketersediaan tanaman pangan ini mengalami fluktuasi dari waktu ke waktu, oleh karena itu untuk memenuhi kebutuhan pangan nasional maka produksi beras nasional perlu ditingkatkan (Deptan, 2008 dikutip Khomawatie, 2010).

Berdasarkan hasil survey Badan Pusat Statistik pada tahun 2012, produksi beras nasional pada Mei 2011-April 2012 sebanyak 20.619.985 ton, dari gabah yang digiling di industri penggilingan padi sebanyak 32.873.663 ton. Kebutuhan masyarakat terhadap beras sekitar $87.235 \mathrm{~kg} / \mathrm{kapita} / \mathrm{tahun}$ (Deptan, 2012) dengan jumlah penduduk Indonesia sekitar 230 juta jiwa, sehingga dibutuhkan sekitar 21 juta ton beras per tahun untuk mencukupi kebutuhan pangan. Permasalahan inilah yang membuat tanaman padi menjadi komoditas yang terus diusahakan dan dikembangkan agar dapat mencukupi kebutuhan pangan masyarakat. Oleh karena itu, Balai Besar Penelitian Tanaman Padi, Sukamandi, Subang bekerja sama dengan Laboratorium Pemuliaan Tanaman Unpad untuk melakukan penelitian pengujian terhadap 30 genotip padi yang diduga berdaya hasil tinggi (Tabel 2) dengan menggunakan 10 marka yang ditunjukkan pada Tabel 1. Marka-marka tersebut dipilih untuk mengkonfirmasi keberadaan dan polimorfisme (perbedaan ukuran) fragmen DNA yang dimiliki oleh 30 padi yang berdaya hasil tinggi koleksi BB Padi. Selain itu, 10 marka tersebut telah dilaporkan berkaitan dengan karakter daya hasil, baik daya hasil langsung maupun karakter komponen hasil, 
seperti jumlah malai, bobot bulir, fase senescence, tinggi tanaman, jumlah anakan, serta kandungan klorofil. Ketiga puluh genotip padi yang memiliki potensi hasil tinggi dan digunakan dalam penelitian ini disajikan pada Tabel 2.

Tabel 1. Primer yang digunakan dalam penelitian

\begin{tabular}{|c|c|c|c|c|c|}
\hline No. & Primer & Kromosom & Tipe & $\begin{array}{l}\text { Karakter yang } \\
\text { Diduga Terpaut }\end{array}$ & Sumber \\
\hline 1 & RM 259 & 1 & SSR & Jumlah Malai & Gramene (2006) \\
\hline 2 & RM 531 & 8 & SSR & Jumlah Malai & Gramene (2006) \\
\hline 3 & $\mathrm{RMw}-513$ & 5 & SSR & Bobot bulir & Weng et al. (2008) \\
\hline 4 & RM 282 & 3 & SSR & Bobot Bulir & Guo et al. (2009) \\
\hline 5 & FLO & & Gene-Spesific primer & Jumlah Malai & Kyozuka et al. (1998) \\
\hline 6 & OsDOS & 1 & Gene-Specific primer & Fase Senescence & $\begin{array}{l}\text { Kong et al. (2006) } \\
\text { Gramene (2006) }\end{array}$ \\
\hline 7 & OsBLE3 & 5 & Gene-Specific Primer & Tinggi Tanaman & $\begin{array}{l}\text { Yang et al. (2006) } \\
\text { Gramene (2006) } \\
\text { www.bioinformatics.nl }\end{array}$ \\
\hline 8 & MOC1 & 6 & Gene-Specific Primer & $\begin{array}{l}\text { (Tillering control in } \\
\text { rice) }\end{array}$ & $\begin{array}{l}\mathrm{Li} \text { et al. }(2003) \\
\text { www.bioinformatics.nl }\end{array}$ \\
\hline 9 & GLN1;1 & & Gene-Specific Primer & Kandungan Klorofil & Hakeem et al. (2012) \\
\hline 10 & NADH-NAR1 & & Gene-Specific Primer & Kandungan Klorofil & Hakeem et al. (2012) \\
\hline
\end{tabular}

Penelitian ini dilakukan dengan tujuan untuk mengidentifikasi marka-marka yang polimorfik sehingga data yang diperoleh nantinya dapat digunakan untuk seleksi padi berdaya hasil tinggi. Selain itu varietas yang terseleksi dapat dijadikan tetua persilangan untuk perakitan padi berdaya hasil tinggi.

\section{BAHAN DAN METODE}

Percobaan dilakukan terdiri dari beberapa tahapan, yaitu isolasi DNA, spektrofotometri, amplifikasi DNA (PCR), dan elektroforesis. Setiap tahapan percobaan memerlukan bahan yang berbeda.

\section{Bahan Penelitian}

Bahan yang digunakan dalam percobaan molekuler adalah sampel daun dari 30 genotip tanaman padi (Tabel 2), CTAB (Cetyl Trimetil Ammonium Bromide), SDS, isopropanol, etanol 80\%, buffer TE (Tris-EDTA), alkohol $70 \%$, pottasium acetate, cisam (fenol, kloroform, isoamil alkohol), cetakan DNA, gene specific primer dan SSR (Tabel 1), Kappa polymerase, Top Vision Agarose (Fermentas), larutan TBE 0,5 x 6 x loading Dye \#R0611 (Fermentas), Gen Ruller \#SM0311 1kb (Fermentas), Gen Ruller \#SM0311 100bp (Fermentas), Ethidium Bromide (EtBr), dan DNA hasil PCR. Acrylamide 30\%, ammonium persulfate $10 \%$, TBE electrophoresis buffer $5 \mathrm{x}, \mathrm{H}_{2} \mathrm{O}$, TEMED.

\section{Metode Penelitian}

\section{Isolasi DNA Padi}

DNA padi diisolasi dari sampel daun padi muda dengan menggunakan metode CTAB (Cetyl trimethylammonium bromide) (Doyle \& Doyle, 1987 dengan modifikasi). Metode CTAB dilakukan melalui tiga tahap yaitu preparasi ekstrak sel, pemurnian DNA, dan pemekatan DNA. CTAB berfungsi sebagai buffer pengekstrak yang dapat merusak membran menjadi suatu larutan kompleks yang mengandung DNA.

\section{Kuantifikasi dan pengujian kualitas DNA melalui Spektrofotometri}

Pengujian kuantitas dan kualitas DNA genomik hasil isolasi dilakukan dengan mesin Spectrophotometer (Rayleigh UV-9200). Pengujian ini dilakukan untuk mengetahui konsentrasi dan kemurnian DNA. Pengukuran konsentrasi DNA dilakukan pada panjang gelombang $260 \mathrm{~nm}$. Jumlah radiasi UV yang diserap oleh larutan DNA (absorbance $=\mathrm{A})$ sebanding dengan jumlah DNA dalam sampel yang diukur. Hasil pengukuran dicatat dan dianalisis untuk membuat DNA template dengan konsentrasi $20 \mathrm{ng} / \mu \mathrm{L}$ untuk digunakan dalam analisis PCR.

\section{Amplifikasi DNA (PCR)}

Pada tahapan ini, amplifikasi DNA dengan menggunakan PCR membutuhkan temperatur, waktu, dan siklus yang berbeda untuk setiap primernya. Kappa DNA polymerase dimasukan kedalam tube sebanyak 9,5 $\mu \mathrm{L} /$ sample, kemudian primer forward dan reverse masing-masing dimasukan $1 \mu \mathrm{L} /$ sample ke dalam tube, dilanjutkan dengan DNA template 1 $\mu \mathrm{L} /$ sample. Setelah tube dipersiapkan semuanya, kemudian mesin PCR diatur programnya sesuai dengan primer. Primer yang digunakan disajikan pada Tabel 1 
Tabel 2. Daftar genotip yang diteliti dalam penelitian

\begin{tabular}{|c|c|c|c|}
\hline No. & Genotip & Karakter menonjol & Keterangan/Kontributor \\
\hline 1 & Fatmawati & Malai lebat & VUB PTB/BB Padi \\
\hline 2 & Ciherang & Potensi Hasil & VUB eksisting terpopuler/BB Padi \\
\hline 3 & Inpari13 & Umur sangat genjah & VUB promising terpopuler/BB Padi \\
\hline 4 & Silugonggo & Umur sangat genjah & VUB umur sangat genjah/ BB Padi \\
\hline 5 & IR64/TIL 1 & Adaptabilitas luas & VU lama/BB Padi \\
\hline 6 & TIL3 & Potensi hasil & NIL perbaikan IR64/ BB Biogen/IRRI \\
\hline 7 & TIL4 & Potensi hasil & NIL perbaikan IR64/ BB Biogen/IRRI \\
\hline 8 & TIL10 & Potensi hasil & NIL perbaikan IR64/ BB Biogen/IRRI \\
\hline 9 & Huanghuazhan & Potensi hasil & Calon VUB, GSR/BB Padi \\
\hline 10 & Zhongzu14 & Potensi hasil & Calon VUB, GSR/BB Padi \\
\hline 11 & ZX117 & Tanaman tipe ideal & Galur tipe baru, GSR/BB Padi \\
\hline 12 & BP14574b-27-3-1M-3-2*B & Umur ultra genjah & Galur umur ultra genjah/ BB Padi \\
\hline 13 & HIPA8 & Malai lebat anakan sedang & Hibrida/ BB Padi \\
\hline 14 & HIPA Jatim 2 & Daun bendera tegak, malai lebat & Hibrida/ BB Padi \\
\hline 15 & Ketan Putih (4655) & Anakan paling banyak & Plasma Nutfah/ BB Padi \\
\hline 16 & Berem Batu (7818) & Anakan paling sedikit & Plasma nutfah /BB Padi \\
\hline 17 & Padi Hungkai (3339) & Jumlah gabah paling banyak & Plasma nutfah /BB Padi \\
\hline 18 & Nipponbare & Jumlah gabah paling sedikit & Plasma nutfah /BB Padi \\
\hline 19 & BP14356e-1-B & Galur sangat tegak & Galur harapan/ BB Padi \\
\hline 20 & $\begin{array}{l}\text { B11143D-MR-1-PN-3-MR-3- } \\
\text { Si-2-3-PN-1 }\end{array}$ & PTB & Galur tipe baru/BB Padi \\
\hline 21 & B12404E-MR-20-PN-3-3 & PTB & Galur tipe baru/BB Padi \\
\hline 22 & B12344-3D-PN-37-6 & PTB & Galur tipe baru/BB Padi \\
\hline 23 & B12411E-MR-9-4-1 & PTB & Galur tipe baru/BB Padi \\
\hline 24 & B12512E-MR-14-PN-1-3 & PTB & Galur tipe baru/BB Padi \\
\hline 25 & PK21 & Potensi hasil & Tetua hibrida/BB Padi \\
\hline 26 & PK88 & Potensi hasil & Tetua hibrida/BB Padi \\
\hline 27 & IPB 3S & Variasi daun bendera & VUB/IPB \\
\hline 28 & IPB159-F-3-1 & Variasi daun bendera & Galur harapan/ IPB \\
\hline 29 & IPB159-F-17-1 & Variasi daun bendera & Galur harapan/ IPB \\
\hline 30 & IPB160-F-3-3-1 & Variasi daun bendera & Galur harapan/ IPB \\
\hline
\end{tabular}

\section{Elektroforesis dan Visualisasi}

Produk amplifikasi dielektroforesis dengan menggunakan gel agarose $3 \%$ dan atau polyacrylamide gel electrophoresis (PAGE) 8\%. Gel agarose 3\% digunakan untuk elektroforesis beberapa primer seperti FLO, OSDOS, GLN1, dan NADHNAR1 yang merupakan gene specific primer, sedangkan empat primer SSR dan dua gene specific primer lainnya menggunakan PAGE dikarenakan pada gel agarose tidak memperlihatkan polimorfisme. Selain itu, gel akrilamida mampu mendeteksi lebih banyak alel per lokus apabila susunannya berbeda 2bp.

Visualisasi dilakukan dengan menggunakan alat gel documentation system (Syngene) untuk melihat fragmen-fragmen DNA yang berbentuk pita-pita DNA. Setiap ukuran pita DNA berhubungan dengan karakter yang akan diamati.

\section{Analisis Data}

Analisis data molekuler dilakukan dengan skoring pita hasil visualisasi DNA. Setiap pita yang muncul pada gel merupakan alel tertentu. Alel tersebut diterjemahkan menjadi data biner yang diberi nilai berdasarkan ada tidaknya suatu alel (Hairinsyah, 2010). Nilai satu atau (+) akan diberikan apabila terdapat alel, dan nilai 0 atau (-) bila tidak terdapat alel.
Analisis persentase alel polimorfis dihitung untuk melihat berapa persen alel polimorfisme yang terbentuk di setiap primer yang digunakan. Untuk menghitung persentase pita polimorfis, digunakan rumus:

$$
\text { Persen Polimorfis }=\frac{\text { Jumlah alel polimorfis }}{\text { Total alel }}
$$

Tingkat keinformatifan primer ditentukan dengan cara penghitungan Polymorphic Information Content (PIC) (Hildebrand, 1992) dengan menggunakan program online PIC Calc yang tersedia di http://www.genomics.liv.ac.uk/animal/Pic1.html.

Nilai PIC dijadikan standar untuk mengevaluasi marka genetik berdasarkan pita DNA hasil amplifikasi PCR, oleh karena itu nilai PIC dibagi menjadi tiga kelas yaitu PIC $>0,5=$ sangat informatif, kemudian $0,25>$ PIC $>0,5=$ sedang, dan PIC $<0,25=$ rendah .

\section{HASIL DAN PEMBAHASAN}

Dari 10 primer yang digunakan, terpilih 6 primer yang polimorfis seperti yang disajikan pada Tabel 1 . Berdasarkan Tabel 3, maka dapat dilihat bahwa primer-primer yang memiliki sifat polimorfis, yang menghasilkan sekitar 2-5 alel. Persentase polimorfis setiap primer pun berbeda-beda. Sedangkan empat primer lainnya belum dapat mengamplifikasi dengan 
baik yang mungkin disebabkan karena program PCR nya yang belum tepat. Selain itu, primer yang tidak sesuai dengan sekuens DNA padi yang diteliti, juga dapat menyebabkan produk tidak teramplifikasi karena tidak terdapat kecocokan yang komplemen antara DNA padi dengan sekuens primer yang digunakan. Primer-primer yang informatif ditunjukkan oleh nilai PIC $\geq 0,5$ (Zhang et al., 2011), sedangkan primer yang memiliki nilai PIC yang semakin besar merupakan primer terbaik yang dapat digunakan sebagai penanda molekuler seperti primer
OSBLE 3, MOC1, dan RM 259. Nilai PIC untuk 6 primer terpilih berkisar antara 0,1-0,76. Nomor tanaman yang terseleksi oleh 6 primer yang polimorfis yaitu sampel \#1 (Fatmawati), \#3 (Inpari13), dan \#30 (IPB 160-F-3-3-1). Ketiga genotip tersebut dapat direkomendasikan sebagai tetua untuk persilangan guna perakitan padi yang berdaya hasil tinggi. Salah satu contoh hasil elektroforesis PAGE dengan menggunakan marka MOC1, disajikan pada Gambar 1.

Tabel 3. Daftar primer yang terpilih

\begin{tabular}{|c|c|c|c|c|c|c|c|}
\hline No. & Primer & $\begin{array}{c}\text { Karakter } \\
\text { terpaut }\end{array}$ & $\begin{array}{l}\text { Jumlah alel } \\
\text { polimorfis }\end{array}$ & $\begin{array}{c}\text { Terdapat pada padi } \\
\text { nomor }\end{array}$ & $\begin{array}{l}\text { Polimorfis } \\
(\%)\end{array}$ & PIC & Sumber \\
\hline 1 & FLO & $\begin{array}{l}\text { Jumlah } \\
\text { Malai }\end{array}$ & 2 & $\begin{array}{l}1,2,4,6,7,10,13, \\
14,17,18,21,22,24, \\
27\end{array}$ & 100 & 0,1167 & $\begin{array}{c}\text { Kyozuka et al. } \\
\text { (1998) }\end{array}$ \\
\hline 2 & OSBLE3 & $\begin{array}{l}\text { Tinggi } \\
\text { Tanaman }\end{array}$ & 4 & $\begin{array}{l}1,3,5,7,8,11,13 \\
20,25,30\end{array}$ & 100 & 0,5786 & $\begin{array}{l}\text { Yang et al. } \\
\quad(2006)\end{array}$ \\
\hline 3 & MOC1 & $\begin{array}{l}\text { Tillering } \\
\text { control in } \\
\text { rice }\end{array}$ & 2 & $\begin{array}{l}1,2,3,4,5,6,7,8,16 \\
17,18,19,20,21,22 \\
23,24,25,26,28,29 \\
30\end{array}$ & 100 & 0,3146 & Li et al. (2003) \\
\hline 4 & OSDOS & $\begin{array}{l}\text { Fase } \\
\text { Senescence }\end{array}$ & 2 & $\begin{array}{l}1,2,3,4,5,6,7,9 \\
11,12,13,14,15,16, \\
17,18,19,21,22,23, \\
24,25,26,27,28,29 \\
30\end{array}$ & 100 & 0,2905 & $\begin{array}{l}\text { Kong et al. } \\
\quad(2006)\end{array}$ \\
\hline 5 & RM 259 & $\begin{array}{l}\text { Jumlah } \\
\text { Malai }\end{array}$ & 3 & $\begin{array}{l}1,2,3,18,22,23,24 \\
25,26,27,28,29,30\end{array}$ & 100 & 0,5622 & Gramene (2006) \\
\hline 6 & RM 282 & Bobot Bulir & 5 & $\begin{array}{l}1-30 \text { kecuali } 18,25 \\
26,27\end{array}$ & 80 & 0,765 & $\begin{array}{l}\text { Guo et al. } \\
\text { (2009) }\end{array}$ \\
\hline
\end{tabular}

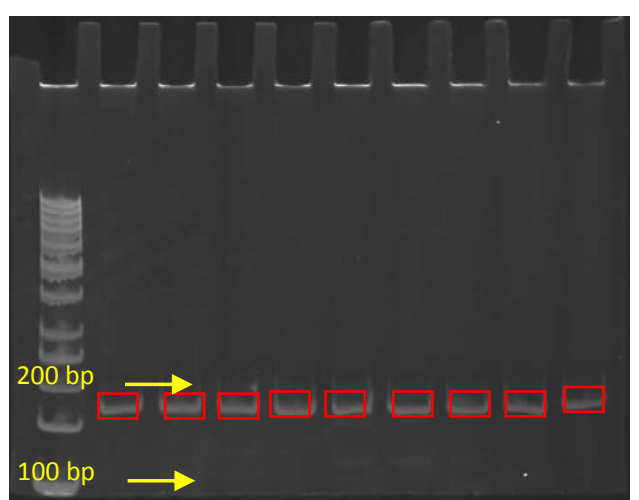

Gambar 1. Pola pita DNA padi genotip \# 19-27 menggunakan marka MOC1.

IR64 merupakan varietas padi hibrida yang memiliki karakter jumlah anakan terbanyak jika dibandingkan dengan varietas unggul lainnya berdasarkan deskripsi varietas padi (BB Padi, 2010). IR64 memiliki jumlah anakan produktif sekitar $20-35$ batang, sehingga digunakan sebagai kontrol untuk karakter tersebut. Berdasarkan hasil visualisasi DNA menggunakan primer MOC 1 yang digunakan untuk mendeteksi gen yang mengendalikan jumlah anakan, terlihat bahwa sampel \#19 (BP14356e-1-B), \#20 (B11143D-MR-1-
PN-3-MR-3-Si-2-3-PN-1), \#21 (B12404E-MR-20PN-3-3), \#22 (B12344-3D-PN-37-6), \#23 (B12411EMR-9-4-1), \#24 (B12512E-MR-14-PN-1-3), \#25 (PK21), dan \#26 (PK88) memiliki pita yang sama dengan sampel \#5 (IR64). Selain itu, sampel \#1, \#2, \#3, 4 (Silugonggo), \#6 (TIL3), \#7 (TIL4), \#8 (TIL10), \#16 (Berem Batu 7818), \#17 (Padi Hungkai), \#18 (Nipponbare), \#22 (B12344-3D-PN-37-6), \#23 (B12411E-MR-9-4-1), \#24 (B12512E-MR-14-PN-13), \#25, \#26, \#28, \#29, dan \#30 juga memiliki pita yang sama dengan IR64.

\section{KESIMPULAN}

1. Dari sepuluh marka yang digunakan, diperoleh enam marka yang polimorfis, yaitu FLO, OSLBE3, MOC1, OSDOS, RM 259, RM 282.

2. Marka yang informatif ditunjukkan oleh OSBLE 3, RM282 dan RM 259.

3. Genotip-genotip yang terseleksi oleh marka molekuler yang berkaitan dengan potensi hasil tinggi yaitu Fatmawati, Inpari13, IPB 160-F-3-3-1. Ketiga genotip tersebut dapat direkomendasikan sebagai tetua persilangan dalam perakitan padi yang berdaya hasil tinggi. 


\section{UCAPAN TERIMAKASIH}

Terimakasih disampaikan kepada Balai Besar Penelitian Tanaman Padi, Sukamandi, Subang yang telah mendanai sebagian penelitian ini melalui Dana Konsorsium Padi Nasional.

\section{DAFTAR PUSTAKA}

Badan Pusat Statistik, (2012). Available at: http://www.bps.go.id/?news=955.

Departemen Pertanian, (2012). Available at : http://www.deptan.go.id/Indikator/tabe-15bkonsumsi-rata.pdf.

Doyle, J.J. \& Doyle, J.L. (1987). Isolation of plant DNA from fresh tissues. Focus, 12, 13-15.

Gramene, (2006). Oryza Taxonomi. Available at http://www.gramene.org/species/oryza/rice_taxo nomy.html.

Guo, L., Lilian, M., Hua, J., Dali, Z., Jiang, H., Liwen, W., \& Zhenyu, G. (2009). Genetic analysis and fine mapping of two genes for grain shape and weight in rice. Journal of Integrative Plant Biology, 51(1), 45-51.

Hairinsyah, (2010). Pendugaan parameter genetik dan analisa keragaman genetik kelapa sawit (Elaeis guineensis Jacq) dengan marka Simple Sequence Repeat (SSR). IPB. Bogor. Available at http://repository.ipb.ac.id/handle/123456789/ 46891.

Hakeem, K, R.., Ruby, C., Parvaiz, A., Altaf, A., \& Muhammad, I. (2012). Physiological and molecular analysis of applied nitrogen in rice genotypes. Rice Science, 19(1), 1-10.

Khomawatie, I. (2010). Ekspresi fenotipe padi transgenik pembawa gen Csnitr1-L terhadap variasi dosis pemupukan nitrogen. Institut
Pertanian Bogor. Available at http://repository.ipb.ac.id/bitstream/handle/1234 56789/59280/ G10ikh.pdf.

Kong, Z., Yang, W., Xue, Y., Li, M., \& Xu, W. (2006). A novel nuclear-localized CCCH-type zinc finger protein, OSDOS, is involved in delaying leaf senescence in rice (Oryza sativa $L$ ). Plant physiology, 141(4), 1376-1388.

Kyozuka, J., Saeko, K., Keisuke, N., Takeshi, I., \& Ko, S. (1998). Down-regulation of RFL, the FLO/LFY homolog of rice, accompanied with panicle branch initiation. Proc Natl Acad Sci USA, 95(5), 1979-1982.

Li, X., Qian, Q., Zhiming, F., Yonghing, W., Guosheng, X., Dali, Z., Xiaoqun, W., Xinfang, L., Sheng, T., Fujimoto, H., Ming, Y., Da, L., Bin, H., \& Jiang, L. (2003). Control of tillering in rice. Nature, 422, 618-621.

Sambrook, J., \& David, W.R. (1989). Molecular Cloning, A Laboratory Manual.

Weir, B.S. (1990). Genetic Data Analysis: Methods for Discrete Genetic Data Sunderland Massachusetts. Sinauer Associates.

Weng, J., Suhai, Gu., Xiangyuan, Wan., He, Gao., Tao, Guo., Ning, Su., Cailin, L., Xin, Z., Zhijun, C, Xiuping, G., Jiulin, W., Ling, J., Huqu, Z., \& Jianmin, W. (2008). Isolation and intial characterization of GW5, a major QTL associated with rice grain width and weight. Cell Res, 18(12), 1199-209.

Yang, G., Ichikawa, H., Komatsu, S., Nakamura, H., \& Kitano, H. (2006). OsBLE3, a brassinolideenhanced gene, is involved in the growth of rice. Phytochemistry, 67, 1442-1454. 